\title{
Burning the Grassroots: Chen Boda and the Four Cleanups in Suburban Tianjin
}

\author{
JEREMY BROWN
}

\begin{abstract}
Chen Boda's four cleanups model in Xiaozhan, a marshy area southeast of Tianjin, was as important as Wang Guangmei's Taoyuan brigade in 1964, but is less well known. As Chairman Mao's top theorist and the editor of Red Flag, Chen Boda enjoyed support from Mao and Liu Shaoqi as he uncovered evidence of 'revisionism' in Tianjin's south suburbs. Chen's claims led to a witch-hunt that killed tens of people and tortured and imprisoned many others. Beyond Tianjin, the 'Xiaozhan experience' was promoted as a successful 'power seizure' in a central document circulated nationwide in October 1964. The document pushed the socialist education movement in a more radical direction, causing the downfall of rural cadres across China. This article draws upon archival sources, memoirs, and interviews to detail Chen Boda's contentious interactions with Tianjin officials and suburban villagers. Chen allowed the four cleanups to turn brutal in Xiaozhan, and his vision of a rural China dominated by class enemies differed from what work team members experienced. Ironically, in order to keep the Xiaozhan experience from falling apart, Chen had to resort to methods similar to those used by the village cadres he had recently overthrown. Chen Boda's meddling in Xiaozhan reveals considerable diversity - and indeed, confusion - in how top leaders interpreted and carried out Mao's shifting plans for the countryside during the four cleanups. This confusion led to disastrous outcomes for rural residents.
\end{abstract}

Keywords: Four Cleanups, Tianjin, Chen Boda, work teams, rural models

On an inspection visit to suburban villages outside of Tianjin in 1960, top party theorist Chen Boda approached a group of peasants. Eager to make conversation, the editor of Red Flag greeted them: 'Are you fishing'? The anglers responded in the affirmative, but demurred when Chen, ever alert to signs of illicit market activity, asked if they planned to sell the fish. 'It seemed that they did not want to pay attention to us', Chen recalled as he recounted the story four years later (Chen Boda 1964: 3940). ${ }^{1}$ But after Chen asked about local crops, the group warmed to him and chatted as they walked toward Tuozidi, a village of 500 people. Chen was in Xiaozhan, a marshy area between Tianjin and the Bohai gulf. 
The most well-known person from Tuozidi was Jiang Deyu, a rice specialist and national labour model who had visited the Soviet Union and met with Chairman Mao Zedong. But when the peasants brought up 'labour model Jiang', Chen Boda had no idea who they were talking about. One local jumped at the opportunity to complain to a top party leader. 'Are we not supposed to emphasize class struggle now? We think that labour model Jiang is a landlord, or at least a rich peasant', Chen recalled the peasants telling him. 'He has cheated our Xiaozhan'.

Chen asked his Tianjin colleagues to investigate Jiang, who was quietly stripped of his honours and kicked out of the party in 1962. Chen was impressed with his seemingly successful foray into rural work. 'Why was it that I went for only two hours and I learned about the matter, but many local comrades had been there for more than ten years and did not know about it? Why were the masses willing to tell me this, but not willing to tell others'? The key, Chen reckoned, was his attitude. 'The masses check you out and see if they can bare their heart to you', he said. 'I am a very stupid person, and have very little experience in working with the masses, but no matter how bad you are, as long as your attitude is correct, you can quickly discover problems'.

Chen's positive experience in suburban Tianjin led him to return to Xiaozhan in March 1964 during the four cleanups campaign, much to the regret of local cadres. Chen quickly discovered other problems. He charged that class enemies had not only hidden their true identities, they had usurped village leadership and enjoyed protection from higher-ups. Chen's claims led to a witch-hunt that implicated thousands of villagers, killed tens of people, and tortured and imprisoned many others in Tianjin's south suburbs. Beyond Tianjin, the 'Xiaozhan experience' was promoted as a successful 'power seizure' in a central document circulated nationwide in October 1964. Bo Yibo, who was vice premier at the time, recalled that the report on the Xiaozhan experience was responsible for pushing the socialist education movement in a more radical direction, causing the downfall of many rural cadres across China (Bo 1993, Vol. 2: 1123-24).

Chen Boda's misreading of rural reality was disastrous for people in Xiaozhan. He went there looking for evidence of class struggle, and he found it right away. Yet he failed to appreciate the pressures on rural cadres to bend rules in order to help their villages survive, let alone prosper. By the time Chen figured out how villages really got by under the collective economy, he was forced to break the rules himself in order to keep the 'Xiaozhan experience' from falling apart. But for 
many residents of Tianjin's south suburbs, the damage had already been done.

Chen Boda's adventures in Xiaozhan were carried out with the approval of both Mao Zedong and Liu Shaoqi. In June 1964, Mao mentioned Xiaozhan as evidence that revisionism had already appeared in China (Bo 1993, Vol. 2: 1116). When Chen supervised the drafting of the nationally circulated report on Xiaozhan, he claimed that he was acting on Mao's orders (Quan 1993: 91). And Liu Shaoqi penned party centre's introductory directive about the report when it was finally issued in late October (Bo 1993, Vol. 2: 1122). ${ }^{2}$ At the time, the Xiaozhan four cleanups model was as important as Wang Guangmei's famous Taoyuan brigade.

Xiaozhan is barely mentioned in western scholarship on the socialist education movement. Limited sources have required most studies to rely on Cultural Revolution era documents that vilify the 'false four cleanups' in Taoyuan but keep mum on Xiaozhan. Richard Baum's classic work devotes an entire chapter to Taoyuan but does not mention Xiaozhan (Baum 1975). More recent works refer to Xiaozhan and Chen Boda, but only briefly (MacFarquhar 1997; Friedman, Pickowicz and Selden 2005). Why the silence? Liu Shaoqi and his wife Wang Guangmei were under attack in 1967, while Chen Boda was doing the attacking. Chen's four cleanups model, like Taoyuan, had been cast aside after Mao criticized the 'human wave tactic' of sending huge work teams to villages at the end of 1964. But unlike Liu Shaoqi, 'Chen refocused his loyalties back to Mao just in time' after Mao issued the moderating 'twenty-three points' in January 1965 (MacFarquhar 1997: 426). Chen Boda's meddling in Xiaozhan reveals considerable diversity - and indeed, confusion - in how top leaders interpreted and carried out Mao's shifting plans for the countryside during the four cleanups. In Xiaozhan and elsewhere, this confusion led to disastrous outcomes for many villagers.

At first glance, Chen Boda's Xiaozhan model looks quite similar to the 'Taoyuan experience' sponsored by Wang Guangmei and Liu Shaoqi. The four cleanups in Xiaozhan and Taoyuan featured large outside work teams that attacked official graft and corruption, squelched illicit market activity, and overthrew village leaders en masse. Violent interrogation methods and struggle sessions were common in each locale. Chen and Wang both diverted substantial sums from state coffers for infrastructure development and fresh paint in their respective models (Baum 1975: 89). Yet there were significant differences between the Xiaozhan and Taoyuan experiences. These differences help to explain 
why Chen Boda's risky adventure in Xiaozhan did not land him in the same political hot water that burned Wang Guangmei and Liu Shaoqi after their Taoyuan intervention.

Chen's aggressive focus on the danger posed by rural class enemies in positions of power distinguished the four cleanups movement in Xiaozhan. Mao Zedong's wishes for the four cleanups evolved over time and were often unclear. Luckily for Chen Boda, his constant referral to class struggle and capitalist restoration ended up being closer to what the chairman wanted than Liu and Wang's more exclusive focus on rural corruption. Also, unlike Wang Guangmei in Taoyuan, Chen did not wear a disguise, travel incognito, or hide his intentions. Ever since his first visit to Xiaozhan, Chen had been loud and clear about the need to battle against counter revolutionaries and to 'seize power' from suspect rural cadres. This aspect of Chen's four cleanups - and not the huge outside work teams and broad scope of attack that Chen and Wang Guangmei shared - is what Mao remembered about Xiaozhan, helping Chen to avoid major political damage in late 1964 and early $1965 .{ }^{3}$ The people of Xiaozhan were not as fortunate.

\section{Chen Boda Gets his Feet Muddy}

Xiaozhan, like much of the area southeast of Tianjin, used to be underwater. After the sea retreated, reedy marshland was gradually populated by migrants from north China. Many villages did not appear on the map until two developments during the late Qing dynasty: first, the discovery that the wetlands were perfect for paddy rice cultivation; and second, the establishment of Yuan Shikai's Beiyang military training camp (Xie 2004: 15). After the army's arrival, Xiaozhan township, 30 kilometres from Tianjin's city centre, developed quickly, and by 1964 had a population of 11,000 . Its proximity to urban Tianjin oriented the region's rice, vegetables, and handicrafts, primarily woven reed products, toward the city. When Chen Boda visited Xiaozhan, the area's political and economic fortunes were still closely tied to Tianjin.

The four cleanups in Tianjin's outskirts began with little hint of the turmoil to come. In January 1964, the Tianjin municipal government established test points in the south suburbs: one in Xiaozhan commune (headquartered in the township and in charge of surrounding villages), and another in Beizhakou commune, five kilometres northwest of Xiaozhan township. The work teams sent to the south suburbs included city and suburban cadres and recent university graduates. Their initial findings, reported in March 1964, were unremarkable. The 
class composition of the area was complicated, owing to the motley mix of migrants who had settled its villages over the past 70-80 years. Land reform in 1951 and a reassessment in 1954 had been mild, which allowed class enemies to falsely claim poor peasant status. Some of them had even wormed their way into leadership positions. But the overall achievements of the region were noteworthy, most cadres were good, and those who had committed mistakes were to be treated leniently (Xie 2004: 16; Liu 2000: 220). At this point, it appeared that Xiaozhan's four cleanups would be 'brief and uneventful', much like in Hebei's Raoyang county, where rural leaders used the movement to reward friends with politically valuable 'poor peasant' class labels and punish rivals with damning 'rich peasant' and 'landlord' labels (Friedman, Pickowicz and Selden 2005: 54, 61).

The first sign that Xiaozhan's four cleanups were special was the appearance of Zhou Yang, deputy director of the central propaganda department. Zhou went to the Tianjin region in late February to interview sent-down youth, but thanks to a few words from Chairman Mao, Zhou changed his itinerary. Mao, who was upset that writers and artists were not serving workers and peasants, ordered Zhou to spend time at the grassroots. 'If he is unwilling to go, then order the army to force him to go down', Mao told Chen Boda. Ostensibly out of concern for Zhou Yang's health, Chen and Tianjin officials arranged for Zhou to stay somewhere close to the city. They settled on Xiyouying, a village of 1,100 people in Beizhakou commune (Chen 2005: 248).

Zhou stayed in the nicest home in Xiyouying, which belonged to female party secretary and labour model Zhang Fengqin and her husband Yu Zhanhai, who was also a local cadre. Zhou did not reveal his official position, saying he was merely a writer hoping to 'experience life' (Wang Kangzhi jinian wenji bianjizu 2001: 124). But village life confused Zhou Yang. Some villagers criticized Zhou's host, who had been featured just weeks earlier in a Tianjin Daily profile about her honest words and deeds (Tianjin ribao, 2 February 1964). When Tianjin propaganda chief Wang Kangzhi visited Zhou to see how he was doing, Zhou said, 'The more I learn about problems here, the more complicated they get. I am like a doctor who can only inquire about a patient's condition but cannot write a prescription' (Wang Kangzhi jinian wenji bianjizu 2001: 124).

Enter Chen Boda, who would not hesitate to issue prescriptions. Chen's quick discovery of labour model Jiang Deyu's problems, combined with his awareness of Mao's concerns about revisionism and class struggle, encouraged him to take charge of Xiaozhan's four cleanups. 
The movement was meant to fix rural maladies that had spun out of control during and after the Great Leap famine, such as corrupt village cadres who wined and dined at state expense, or who underreported harvest numbers in order to reduce the amount of grain requisitioned by the state. Black market trading, profit-making rural sidelines, and private agricultural plots were also dangerous signs that China's countryside had already turned revisionist. There was also the trumped-up fear that class enemies who had avoided detection during land reform were in positions of power, continuing to exploit poor peasants. In a conversation with Tianjin mayor Hu Zhaoheng, Chen Boda explained why these problems were so common: 'Putting together a whole socialist system is not easy. Even after many decades, the systems established by past dynasties were not perfect, much less so this new system that is eliminating exploitation' (Quan 1993: 92). Chen was suggesting that his goal in Xiaozhan was to move toward eradicating exploitation in China's villages. In order to do so, he had to target the wealthiest, most powerful villagers he could find.

In March 1964, Chen Boda dropped in on Tianjin first party secretary Wan Xiaotang before heading to Xiaozhan. ${ }^{4}$ On at least three previous occasions, Wan and Chen had clashed when Chen passed through Tianjin. In summer 1961, Chen told Tianjin officials in charge of economic planning that Tianjin was his 'second hometown' and that he would come every year. But Chen's visits never turned out the way he wanted. Wan Xiaotang repeatedly shelved Chen's suggestions on how to improve Tianjin's industrial development, calling Chen's ideas 'divorced from reality', and privately grumbling that the vaunted theorist's 'ideology was lacking' (Li 1998: 201-2, 204; Xie 2004: 21). Chen, feeling snubbed, said that 'this Wan Xiaotang is no good', and complained, 'Tianjin does not obey me, I will not go there anymore' (Xie 2004: 21; Wan Xiaotang jinian wenji bianjizu 2001: 408). But in 1964, Chen could not stay away. Having failed to influence Tianjin's urban industry, he turned his attention to its rural hinterland. Chen listened quietly as Wan Xiaotang reported on the excellent economic performance of Tianjin's south suburbs. Wan assured Chen that Liu Jinfeng, first party secretary of the south suburbs, was a 'good comrade' and that there were several enthusiastic labour models in the Xiaozhan area (Xie 2004: 19).

Liu Jinfeng, who had served as suburban party secretary since 1953, accompanied Chen to Xiyouying. As their car neared the village, Chen ordered the driver to stop. He stepped out of the car, looked around, and began speaking quickly. Liu found Chen's Fujianese accent incom- 
prehensible, but finally understood that Chen wanted to walk the final half kilometre to the village. Chen was saying that entering the village in a car would distance them from the masses. After hearing a report from the four cleanups work team stationed in Xiyouying, Chen visited Zhang Fengqin's house, where Zhou Yang was staying. Chen took note of the three new outbuildings in Zhang's compound, saw hefty bags of rice stacked up inside, and fixated on something he had never seen in villages before: double-glazed glass windows. After twenty minutes, Chen had seen enough. He told Zhou Yang to move to a poor peasant's house, where Zhou would stay until returning to Beijing in May. Chen then went to report his findings to the work team. 'Zhang Fengqin does not seem like a poor peasant, her family is richer than all other villagers. She got rich after becoming party secretary', Chen said. 'The doubleglazed glass exposed Zhang Fengqin. She is a poor peasant who is not really poor, a labour model who does not labour, she has become a politicized figure'. Something had to be done, Chen told the work team. 'You can tell with just one look that she is the enemy. You take care of this, we cannot have mistakes here,' he ordered (Liu 2000: 204-5; Wang 2004: 207). When he returned to Tianjin, he told city officials that Zhang should be removed from her leadership positions.

The work team jumped into action and quickly assembled evidence of Zhang's crimes, which included illegally profiting from seven village factories established during the early 1960s, lowballing harvest reports and keeping excess grain for the village, and hiding her true class identity as a rich peasant (Zhonggong zhongyang dangxiao dangshi jiaoyan er shi 1987, Vol. 5: 488-89). This verdict came as a shock to Liu Jinfeng, who had spent years promoting Zhang Fengqin as a star female village leader. Zhang had organized Xiyouying's first mutual aid society and its first cooperative in the 1950s. Now she was being attacked because her house did not conform to what Chen Boda thought a village cadre's home should look like. Liu saw Xiyouying's wealth not as a crime, but as evidence of his successful stewardship of the suburbs. 'According to [Chen Boda's] logic, poor peasants had to be utterly penniless forever', Liu wrote (Liu 2000: 213).

The actual situation was more complicated than Liu Jinfeng suggests. Chen Boda was indeed disturbed by what he saw as excessive wealth in the countryside (during a 1960 visit to a village in Wuqing county, between Beijing and Tianjin, Chen visited a large family compound, saw a towering pile of thick quilts on the kang, and 'felt it was very strange'; Chen 1964: 39). But factional disputes and political manoeuvring also 
came into play. By targeting Zhang Fengqin, Chen Boda took pressure off of her main rival, deputy village party secretary $\mathrm{Wu}$ Fengchun. $\mathrm{Wu}$ had been complaining about Zhang's false harvest reports for several years. The four cleanups work team in Xiyouying, well aware that Zhang had been praised in Tianjin Daily and was favoured by suburban and municipal leaders, already had a 7,000 character document denouncing her potential usurper Wu (Tianjin ribao, 18 August 1970). Chen Boda's comments about Zhang shifted the movement's direction and introduced the purported threat of hidden class enemies in leadership positions.

Under-reporting grain yields and investing in profitable sidelines were common survival strategies after the Great Leap famine (Gao 2006; Yang 1996). These practices were also likely to earn village leaders popular support, while cadres who insisted on handing everything over to the state faced grumbling. Ironically, the Tianjin Daily article praised 'honest' Zhang Fengqin for saying, 'however much we harvest, that is what we will report', and chastised villagers who complained that Zhang's honesty put the village at a disadvantage. But it turned out that Zhang had been dishonest, to the advantage of her village. Xiyouying had kept 3,500 kilos of extra grain for itself. The village also invested in sidelines that reportedly earned 400,000 yuan in 'sudden huge profits' (baoli) during the early 1960s, and even rented a long-term room at a Tianjin hotel in order to make business deals in the city (Zhonggong zhongyang dangxiao dangshi jiaoyan er shi 1987, Vol. 5: 488, 503). This was not the socialist system that Chen Boda wanted to build.

Later in March, Chen visited several other sites in Xiaozhan. He returned to Tuozidi, where farmers had complained about labour model Jiang Deyu four years earlier. It was rainy, but Chen again insisted on walking into the village. He took off his shoes and socks, slipping and sliding through the mud. For lunch, villagers had prepared a substantial meal with several dishes, steamed buns, and rice. When Chen saw the food, he shook his head and indicated that he would not eat it. He refused to 'eat big and drink big', one of the main crimes village officials were accused of during the four cleanups. Chen said he would have a corn bun, and his village hosts rushed off to make some. Stomachs growling, none of Chen's entourage from Tianjin and the south suburbs dared to touch the food on the table. When the buns were ready, Chen divided one up and passed pieces around before taking two bites and declaring the meal finished. Chen then complained that even though Jiang Deyu had been cashiered in 1962, he was still in charge behind 
the scenes in Tuozidi. Jiang would also have to become a struggle target during the four cleanups, Chen instructed (Liu 2000, 206-207).

Chen thought that he had found a good formula for getting close to the masses and discovering problems in the suburbs. This was a variation of the 'three togethers', the practice of eating, living, and working with poor peasants that all work teams were supposed to follow. Chen stayed in a colonial-style guesthouse in Tianjin's former British concession, where he enjoyed privately screened films (including one about the life of Beethoven, Quan 1993: 83). He did not do farm work, but when he went to the countryside he followed a plan to make himself seem down-to-earth. First, walk into villages, even if your feet get muddy. Second, be seen eating simple food. Finally, be on the lookout for signs of excessive wealth. Chen had learned these lessons during his 1960 visit to Xiaozhan, when he insisted on eating a meagre vegetable bun. In late 1964, he told a group of writers and editors preparing to join village work teams that his attention to appearances had paid off. 'Recently I went back there and two peasants pointed at me from afar and said, "that old man wearing glasses came here in 1960 and ate a vegetable bun. Now he's back". All I did was eat once and the common people remembered it', Chen said proudly (Chen 1964: 40).

After 1964, people in Xiaozhan would remember Chen's accusations during the four cleanups more than his bun chewing. After Tuozidi, Chen's next stop was Xiaozhan township, where he decided that township party secretary Zhang Yulun was actually a class enemy from a 'bandit family'. Chen had made his intentions clear. Over the next two months, work teams reinforced by new members transferred to suddenly important Xiaozhan compiled materials on three 'counter revolutionary cliques' centred around female labour model Zhang Fengqin, rice specialist Jiang Deyu, and township leader Zhang Yulun. Each clique included between 75-90 people, who were criticized at mass meetings. Anyone with ties to the counter revolutionaries also came under suspicion: one official source reports that 2,711 people in the south suburbs were implicated in 'mistaken cases' during the four cleanups (Tianjin shi Jinnan qu difang zhi bianxiu weiyuanhui 1999: 425).

\section{Xiaozhan's Shocks}

Tianjin leaders helped to push the movement in a violent direction by endorsing Chen Boda's verdict on the cliques' three ringleaders. By the end of April 1964, Zhang Fengqin was kicked out of the party and her husband was arrested. Chen, who had finally got his way after being 
ignored in previous years, remarked approvingly, 'the Tianjin party committee is not all that bad' (Tianjin shi Jinnan qu difang zhi bianxiu weiyuanhui 1999: 847). Jiang Deyu was detained in July; Zhang Yulun remained free until December, although his party membership and leadership positions had been removed earlier in 1964 . Once the cliques had been identified and their leaders punished, people with connections to the 'counter revolutionaries' became fair game for inhumane treatment.

Available accounts of the four cleanups identify work team members as the main perpetrators of beatings and torture in Tianjin's south suburbs, although villagers were also involved. According to an official source, there were 29 'abnormal deaths' during Xiaozhan's four cleanups. One former member of a work team there told me that the dead included people who were beaten to death as well as suicide victims (Tianjin shi nongcun hezuo zhi fazhan shi bianji bangongshi 1989: 324). ${ }^{5}$ Chen Boda encouraged this violence after someone told him about a beating in Xiaozhan. 'The masses want to beat him, they have the revolutionary spirit', Chen said. 'First, they are not beating a good person. Second, they did not beat him to death' (Liu 2000: 230-31). Violence occurred on stage at meetings and also during interrogations. At one session, Zhang Fengqin was subjected to the 'swing the coal briquette' torture: one person grabbed her by the hair, another took her legs, and she was swung around violently. Her hair was torn from her head and two of her front teeth fell out (Liu 2000: 231). Zhang tried to hang herself at home, but two female work team members stationed in her house stopped her (Zhonggong zhongyang dangxiao dangshi jiaoyan er shi 1987, Vol. 5: 510; Zhonggong Tianjin shiwei bangongting 1964a: 50). Other rural officials in the Tianjin region heard about the carnage in Xiaozhan and were terrified when work teams arrived during a later phase of the four cleanups. In October 1965, work team members reported that 'because of Xiaozhan's shocks', cadres were afraid of getting killed: 'People say, "as long as I have a breath in my body after the movement is over, it will be okay"' (Jinjiao siqing jianbao, No. 1, 25 October 1965: 7).

Widespread fear was stoked when accusations about almost any perceived transgression-economic, political, or personal-led to humiliation and violent punishment. Some of the harshest criticism and treatment were reserved for alleged sexual improprieties. In the official report about the 'Xiaozhan experience' circulated nationwide and endorsed by party centre, both Zhang Fengqin and Zhang Yulun were singled out for having inappropriate sexual relations (Zhang Fengqin 
with a Xiyouying vice brigade leader, Zhang Yulun with the 'concubine' of a 'landlord-capitalist'; Zhonggong zhongyang dangxiao dangshi jiaoyan er shi 1987, Vol. 5: 511, 490). After the charges against the two village leaders were aired publicly, work team members investigated the sexual histories of lesser targets, sometimes viciously. When one female cadre in a village a mile away from Xiyouying denied charges that she had slept with the village party secretary, work team interrogators stripped her naked and raped her with icicles torn from the eaves of her house (Liu 2000: 231).

According to suburban leader Liu Jinfeng, he was the only official who tried to resist Chen Boda. When the Tianjin party committee approved Chen's suggestion that Zhang Fengqin be dismissed from all of her posts, Liu argued that she was a good cadre. At a work team meeting in Xiyouying in April 1964, Liu departed from his script and said that Zhang would be 'temporarily' removed from her posts. Liu hoped that Chen Boda would research the situation further and realize that Zhang was a genuine revolutionary. He should have known better. Chen was listening carefully, and as soon as he heard the words 'temporarily remove from office', he yelled, 'Liu Jinfeng, what the hell are you doing? Dismissing means dismissing, why are you announcing that it is temporary'? Liu had no response. He turned his head and looked out the window (Liu 2000: 222-23). He may have been watching his political career slip away. Chen Boda complained to Tianjin officials that the 'root' protecting the counter revolutionary cliques could be found in the party office of the south suburbs. By the end of 1964, the south suburbs' party committee had been reorganized and Liu was transferred to the west suburbs as a low-ranking four cleanups work team member. When Liu went to Tianjin's first secretary Wan Xiaotang to complain about his demotion, Wan said that there was nothing he could do: 'Party centre has already approved and circulated [Chen's] report, the Tianjin party committee has to carry it out' (Xie 2004: 20).

Chen Boda was able to have his way in Xiaozhan because Tianjin's leaders assumed that he was acting on Mao's behalf. After Mao said that revisionism had appeared in Xiaozhan, all subsequent reports had to confirm this conclusion. In late July, Tianjin propaganda officials Wang Kangzhi and Fang Ji went to Beijing to prepare the first set of official materials sent to party centre about Xiaozhan: a chronology and a diagram outlining the counter revolutionary cliques' social networks. Chen was proud of the completed product. After work was done, he insisted on accompanying Wang and Fang back to Tianjin in his car. 
Chen said, 'Some people say that scholars cannot do anything. I am a scholar, and Wang Kangzhi does the newspaper, so he is a scholar too. Fang Ji writes novels, he is even more of a scholar. Have we not done something big' (Tianjin shi Jinnan qu difang zhi bianxiu weiyuanhui 1999: 847)? Chen forwarded the documents to party centre on August 4, along with a letter stating, 'the chairman has instructed (zhuxi fenfu guo) that these materials can be circulated down to the county level for everyone's reference'. In case anyone doubted that Mao was backing Chen's activities in Xiaozhan, here was the proof in writing. On 12 August 1964, the chronology and diagram were sent to four cleanups work team directors nationwide. A more exhaustive written report about Xiaozhan was promised to be forthcoming (Xie 2004: 18). During the rest of August, Tianjin cadres hurried to prepare the document.

\section{Lessons Learned, Lessons Ignored}

Wang Hui, director of the Tianjin municipal party committee's general office (shiwei bangongting), drafted the report, titled 'On the Struggle to Seize Power in the Xiaozhan Region'. Wang later regretted his involvement. 'This was the most important document from Tianjin that party centre had circulated since liberation. It was also the document with the worst impact', he wrote (Wang 2004: 197). Wang Hui spent two weeks in Xiaozhan, mostly in Xiyouying, gathering materials for the report. Even though his final report outlined the massive corruption, sexual misconduct, and evil deeds of 'class aliens' Zhang, Jiang, and Zhang, Wang Hui's impression of suburban village life differed from Chen Boda's. This is because Wang, unlike Chen, slept, ate, and went to the bathroom in Xiyouying for an extended period of time. Although 'the lives of the masses in the region were rather prosperous', as Wang noted in his fall 1964 report, he preferred the plumbing in his multi-storey city home. To Wang, Xiaozhan was better off than more isolated rural places, but it was still a far cry from urban life during the 1960s.

Wang Hui followed the three togethers in a peasant home, which meant that his daily diet consisted of onions mixed with shrimp paste. 'There was not even a basic latrine pit in the yard', Wang wrote, 'so going to the bathroom was very difficult'. In retrospect, Wang found it ironic that he and other work team members normally lived in nice buildings equipped with bathrooms, but were struggling against grassroots rural cadres living in mud huts. 'Their small-scale farming lives were extremely far from a capitalist restoration', he wrote (Wang 2004: 206-7). Many work team members were like Wang. They fol- 
lowed orders to struggle against enemies in the countryside, but also privately took note of economic reality.

By late 1964, even Chen Boda could no longer ignore rural economic realities. As the autumn harvest in Xiyouying came around, it became clear that the village's income had fallen drastically since the four cleanups had started and that peasants would receive less grain than they had under Zhang Fengqin's leadership. Unwilling to let his model flounder, Chen went into damage control mode. The first step was to invest funds in improving 'village appearance' (nongcun mianmao). Chen diverted 250,000 yuan for building projects in Xiaozhan, and asked Tianjin economic planners to consider moving city factories there (Tianjin shi nongcun hezuo zhi fazhan shi bianji bangongshi 1988b: 132; Li 1998: 132). Even though village leaders' homes were too luxurious for Chen's tastes, apparently the area needed a makeover. It was standard practice for leaders to lavish state funds on model units - Wang Guangmei had spent even more in Taoyuan. However, architectural improvements would not solve the serious threat that a drop in local incomes posed to the credibility of Chen's model.

During the four cleanups in Xiyouying, the work team learned that Zhang Fengqin had kept 500 mu of 'black land' off the books (Zhonggong Tianjin shiwei bangongting 1964b: 83). Now that the land had been reported, Xiyouying was responsible for handing over more grain to the state. Also, following the four cleanups' attack on money making, the village's sideline income in 1964 plummeted by 44 percent (Tianjin shi Jinnan qu difang zhi bianxiu weiyuanhui 1999: 844). Chen Boda was learning an important lesson about how rural leaders had managed to keep life bearable for villagers. He was frustrated that villagers supported 'bad' cadres and hated 'good' ones. 'Bad cadres hid land and gave too much grain to the masses', he said in Tianjin in late November 1964. 'With good cadres in charge, the hidden land is made public and the masses get less grain. This means that good cadres cannot continue on' (Zhonggong Tianjin shiwei bangongting 1964a: 53). Now Chen understood why Zhang Fengqin enjoyed popular support. 'Since the four cleanups movement, the burden on the masses has increased', he said. 'If I were a common person in Xiyouying, I would also endorse Zhang Fengqin' (Zhonggong Tianjin shiwei bangongting 1964b: 83).

It was unacceptable to Chen that Xiyouying owed more to the state after he had tried to clean up the village's problems. He ordered no requisitioning of grain from the 'black land' for at least three years. ${ }^{6} \mathrm{He}$ also directed Tianjin officials to immediately distribute to villagers 85,000 
kilos of grain that had already been collected and warehoused. When Tianjin propagandist Fang Ji mentioned commune rules mandating that forms had to be filled out before grain could be given to villagers, cranky Chen went on a Mao-like tirade against bureaucracy:

'Why is the commune so bossy? This form, that form, burn them all! They have set up this complicated system that makes it impossible for us to get involved, then they can play tricks. Their crock of a system is hairsplitting and pretentious, they use it to frighten people. Why don't you take care of this! Your four cleanups work team is incompetent! This affects the masses' livelihood, it affects next year's production, but you do nothing about it! The commune is stirring up trouble by doing it this way! Let the masses discuss this and distribute grain however they want' (Zhonggong Tianjin shiwei bangongting 1964a: 54).

Fang Ji made sure that the grain was given out right away, and also carried out Chen's orders that finance authorities forgive outstanding debts owed by Xiyouying villagers.

Chen Boda was discovering how difficult it was to be a village leader. He bent the rules to maximize villagers' incomes, much like Zhang Fengqin had in previous years. Back in the village, Wang Fengchun had benefited greatly from his rival Zhang's downfall. Wang, now Xiyouying's party secretary, owed his new position to Chen Boda. But Wang was unaware that his powerful patron had been pulling strings in Tianjin to distribute more grain to Xiyouying. Wang was still giving speeches attacking Zhang, saying that keeping more or less grain for the village was a struggle between two lines (more grain being capitalist, less being socialist). Now that Chen Boda was acting like Zhang Fengqin had, he needed Wang to shut up. 'His attitude and viewpoint are correct', Chen said about Wang, 'but in policy terms he is mistaken. Comrade Fang Ji, go back and do a bit of persuasion work on Wang Fengchun' (Zhonggong Tianjin shiwei bangongting 1964a: 53). As Chen Boda would soon find out, Wang Fengchun was not the only person who had misread a patron's shifting intentions.

Chen's ability to manipulate events on the ground in the Tianjin suburbs changed along with the overall direction of the four cleanups. Mao's late 1964 critique of Liu Shaoqi's version of the movement also applied to Xiaozhan. The 'twenty-three points', circulated on 18 January 1965, stressed uniting 95 percent of cadres and called for an end to 'human wave tactics', stating, 'we must not concentrate excessively large work teams within a single hsien [xian], commune, or brigade' (Baum 1975: $119,122)$. Chen Boda was chastened. Xiaozhan was a prime example of human wave tactics (more than 5,000 people served on work teams 
there). And instead of uniting 95 percent of cadres, Chen had stated that 'more than 80 percent of grassroots power' in Xiaozhan was 'not in our hands'. Work teams had taken Chen at his word (137 of the 191 cadres in Xiyouying, Tuozidi, and Xiaozhan township were labelled as class enemies within the revolutionary ranks; Liu 2000: 208, 212).

After making a few conciliatory moves in January 1965, including releasing Zhang Fengqin's husband from jail and allowing Zhang to labour under supervision at home, Chen backed off from Xiaozhan's four cleanups (Chen 1999: 58; Tianjin shi nongcun hezuo zhi fazhan shi bianji bangongshi 1988a: 196). The intensity of the movement diminished, and the last work teams left Xiaozhan in September 1965. This was small consolation to people classified as members of counter revolutionary cliques, including Jiang Deyu and Zhang Yulun, who remained in jail. More important, even though the twenty-three points had a temporarily moderating effect, the precedent for violence had been set by Xiaozhan.

Even after the circulation of the twenty-three points, there was considerable variation at the local level as the four cleanups continued throughout 1965. While the worst was over in Xiaozhan and the general trend was toward moderation, violence erupted anew in certain areas. A rash of suicides swept through villages when a new wave of work teams entered Hebei villages in autumn 1965. In October alone, 36 suicides in the Tangshan region were attributed to the four cleanups. In the province as a whole, 533 people had killed themselves during the movement, including 73 in the Tianjin region and 2 within the municipality (Hebei nongcun siqing jianxun, No. 40, 21 November 1965: 1-3). Even though internal reports urged caution and deplored the deaths, leaders like Gu Yunting (Tianjin's party secretary in charge of agriculture and the suburban four cleanups) emphasized the necessity of harsh struggle well into 1966. In a speech to work team political officers, Gu spoke approvingly of the treatment used against Zhang Yulun in Xiaozhan, who 'was struggled against so hard that his sweat soaked the ground' (Hebei nongcun siqing jianxun, No. 98, 6 May 1966: 3-4).

When Tianjin cadres returned to check up on Xiaozhan in spring 1966, they found that the problems they had tried to stamp out had already reappeared. New village cadres who had taken office during the movement were stepping down and refusing to work, and gambling and black market grain trades had become more common (in one village, 40 percent of the population gambled, Hebei siqing tongxun, No. zengkan 15, 20 April 1966: 26; Jinjiao siqing jianbao, No. zengkan 15, 12 May 1966: 
4). Resentment simmered among those who had been targeted during the four cleanups. One former village party secretary became enraged when he ran into four cleanups activists at a public works site, yelling, 'you fucking bastards, you relied on the influence of the movement to oppress people. Come on, let's go one-on-one, I'll get my knife and stab you' (Hebei siqing tongxun, No. zengkan 15, 20 April 1966: 25).

For a while, the outbreak of the Cultural Revolution in mid-1966 and the power seizures that swept the nation in early 1967 gave hope to people in Xiaozhan who felt wronged by the four cleanups. They were spurred on by a group of more than twenty students from Beijing's Politics and Law Institute (Zhengfa xueyuan) who had come to dig up dirt on Chen Boda in December 1966. The students spoke with Zhang Fengqin and targeted her rival, Wang Fengchun. On January 22, 1967, a 'rebel' group allied with the students occupied the Xiaozhan broadcast station (Tianjin ribao, 18 August 1970). Chen Boda would later characterize this event as a 'capitalist restoration', explaining, 'cadres who were removed during the four cleanups came to power or were preparing to return to power. I heard that Xiaozhan was very chaotic for a while' (Zhongyang shouzhang jiejian Tianjin fu Jing daibiao jici tanhua huibian 1967, 10). ${ }^{7}$

Unfortunately for the rebels, they were attacking a project associated with Chen just as he was riding high as leader of the Central Cultural Revolution Group. Their cause was doomed. In 1966 and 1967, Chen Boda felt empowered to build upon what he had 'achieved' in Xiaozhan. In mid-1966, Chen told Zhang Chengxian, head of the work team at Beijing University (Beida), that he wanted to proceed at Beida 'according to the "Xiaozhan four cleanups experience" that he had created' (Zhang Chengxian 1998: 28). ${ }^{8}$ Zhou Enlai also supported Chen, calling him an expert on Tianjin and Xiaozhan in April 1967 (Tianjin fu Jing daibiao 1967: 3).

After Chen heard about what had happened in Xiaozhan, he told Tianjin's new top leader Xie Xuegong, 'there has been a reversal in Xiaozhan. Liu Jinfeng cannot be supported, Xiaozhan's four cleanups cannot be overturned, the facts are completely correct, and party centre knows all about it. In sum, Liu Jinfeng cannot be restored to the throne. Support Wang Chunfeng' (Gandaihui shirenwei xitong jiguan geming ganbu daibiaohui 1967: 2). After this utterance Liu and his wife (former chair of the suburban women's league) were incarcerated in 'cow sheds' and struggled against at mass meetings (Liu 2000: 228).

Those victimized during Xiaozhan's four cleanups would have to wait for relief until well after Chen Boda was purged in late 1970. In a strange episode about which little is known, Chen made a final trip 
to Xiaozhan in June 1970 in order to promote the slogan 'study heroic Xiyouying'. Beginning on 18 August 1970, just as the central committee plenum that would be Chen's downfall was getting underway in Lushan, Tianjin Daily published a week-long series of hagiographic articles about heroic Xiyouying. The first of the articles celebrated the 'great support' provided by a certain 'leading comrade from the proletarian headquarters' during the four cleanups (Tianjin ribao, 18 August 1970). Chen's name did not appear, but anybody reading the article knew it was referring to him. At this point in summer 1970, Chen clearly wanted to remind people that Xiaozhan was his rural model, and that it was thriving. But it was too late for Chen, who was condemned as 'a traitor, spy, and a careerist' at the end of the year (MacFarquhar and Schoenhals 2006: 333).

Even though Chen had been vilified and imprisoned, it took until 1972 for Tianjin to send a team to Xiaozhan to reinvestigate the counter revolutionary cliques. In March 1973, the Tianjin party committee sent a report to party centre concluding that even though Zhang Fengqin and Zhang Yulun had committed serious mistakes, they were 'pretty good cadres', not black gang leaders, rich peasants, bandit family members, or class aliens. Both were rehabilitated, and Zhang Yulun was released from jail. Liu Jinfeng returned as party secretary of the south suburbs. Jiang Deyu was not so fortunate. For reasons that remain unclear, the report concluded that even though Jiang did not lead a 77 person clique, he was still a counter revolutionary and a landlord. His original verdict stood and he remained in jail until he was finally cleared in 1978. A second reinvestigation that began in 1978 finally cleared Jiang Deyu and others of any wrong doing (Tianjin shi Jinnan qu difang zhi bianxiu weiyuanhui 1999: 845-46).

Chen Boda was imprisoned until a year before his death in 1989, but he remained reluctant to admit that he had done anything wrong in Xiaozhan. At a mass denunciation meeting in the southern suburbs in April 1974, officials excoriated Chen (in absentia) for having supposedly boasted, 'On the whole, I did a good thing for the people of Tianjin by carrying out the four cleanups for a year in Xiaozhan. If it were in the past, the common people of Tianjin would build a temple and erect a monument to me' (Zhonggong Tianjin shiwei pi-Lin zhengfeng bangongshi 1974: 3).

Late in his life, Chen's brief comments about the four cleanups in an exculpatory biography compiled by his son were less celebratory about his impact in the Tianjin suburbs. But Chen still defended himself. He 
remembered that when he read in the newspaper about Zhang Fengqin's rehabilitation, he had difficulty accepting that the four cleanups in Xiaozhan had been completely repudiated. What really disturbed Chen was that Zhang Fengqin and her husband were being compensated 4,000 yuan by the collective for the money and property that had been seized from her in 1964. 'Both of them are villagers, both are "cadres", and neither worked. Where could they have got so much money'? Chen wondered. 'Just from this point, I think that the entire case was not necessarily a complete mistake' (Chen 1999: 58; Chen 2005: 248).

Chen may have had a point - today, the party is still wrestling with the question of how to prevent officials from enriching themselves at the public trough - but he was being disingenuous. He knew exactly how Zhang and her husband had made their money, and in 1964 he had already admitted that if he were a villager, he would have supported them. By the end of 1964, Chen was breaking the rules by handing out grain that should have gone to the state. In spite of his largesse, the people of Xiaozhan can be forgiven for not building a temple or monument to honour Chen and the work teams that did his bidding. Villagers were better served by Zhang Fengqin than by the disruptive presence of a central leader like Chen Boda.

Jeremy Brown is Assistant Professor of History, Simon Fraser University (jeremy_brown@sfu.ca)

\section{ACKNOWLEDGEMENT}

This paper was originally presented at the Iceland International Conference on the Mao Zedong Era, organized by the Icelandic Centre of Asian Studies and the Icelandic Chinese Cultural Society. Thanks to Geir Sigurðsson for his work in organizing the conference and shepherding this piece toward publication. I also thank Vivienne Shue and her colleagues at the University of Oxford's Contemporary China Centre for their helpful comments and questions on an earlier draft. Research was supported by a Fulbright-Hays Doctoral Dissertation Research Award and a Social Science Research Council International Dissertation Field Research Fellowship with funds provided by the Andrew W. Mellon Foundation. Writing was supported by a Doctoral Dissertation Fellowship from the Chiang Ching-kuo Foundation. 


\section{REFERENCES}

Baum, R. 1975. Prelude to Revolution: Mao, the Party, and the Peasant Question, 1962-66. New York: Columbia University Press.

Bo Yibo 1993. Ruogan zhongda juece yu shijian de huigu [Reflections on certain major decisions and events]. Vol. 2. Beijing: Zhonggong zhongyang dangxiao chubanshe.

Chen Boda 1964. 'Xiaxiang wenti' [On going to villages]. Reproduced by Hebei shengwei siqing bangongshi, 4 Oct. 1964. Hebei Provincial Archive, 855-19-1045C.

- 1999. Chen Boda yigao: yuzhong zishu ji qita [Manuscripts by the late Chen Boda: accounts from prison and more]. Hohhut: Nei Menggu renmin chubanshe.

Chen Mingyang (ed) 2005. Dangnian shi: Nanfang zhoumo jiemi dang'an [Bygone events: Southern Weekend's archive of unlocked secrets]. Beijing: Wenhua yishu chubanshe.

Chen Xiaonong (comp) 2005. Chen Boda zuihou koushu huiyi [Chen Boda's final oral memoir]. Hong Kong: Yangguang huanqiu chuban Xianggang youxian gongsi.

Friedman, E., P.G. Pickowicz, and M. Selden 2005. Revolution, Resistance, and Reform in Village China. New Haven: Yale University Press.

Gandaihui shirenwei xitong jiguan geming ganbu daibiaohui 1967. Chen Boda tongzhi dui Tianjin gongzuo de zui xin zhishi [Comrade Chen Boda's newest orders on Tianjin work]. Tianjin, 7 Jul. 1967.

Gao Wangling 2006. Renmin gongshe shiqi Zhongguo nongmin 'fan xingwei' diaocha [An investigation into Chinese peasants' 'counteraction' during the commune period]. Beijing: Zhongguo dangshi chubanshe.

Hebei nongcun siqing jianxun [Hebei village four cleanups news in brief].

Jinjiao siqing jianbao [Tianjin suburbs four cleanups bulletin].

Li Zhongyuan 1998. Bashi shuwang [Narrating the past at age eighty]. Tianjin: Tianjin renmin chubanshe.

Liu Jinfeng 2000. Zhengrong suiyue: Liu Jinfeng huiyilu [Extraordinary years: Liu Jinfeng's memoirs]. Tianjin: Tianjin renmin chubanshe.

MacFarquhar, R. 1997. The Origins of the Cultural Revolution: Vol. 3: The Coming of the Cataclysm, 1961-1966. New York: Columbia University Press.

MacFarquhar, R. and M. Schoenhals 2006. Mao's Last Revolution. Cambridge: The Belknap Press of Harvard University Press.

Pang Xianzhi and Jin Chongji 2003. Mao Zedong zhuan, 1949-1976 [The life of Mao Zedong, 1949-1976]. Vol. 2. Beijing: Zhongyang wenxian chubanshe.

Quan Yanchi 1993. Tianjin shizhang [Tianjin mayor]. Beijing: Zhonggong zhongyang dangxiao chubanshe.

Tianjin fu Jing daibiao 1967. Zhongyang he zhongyang wenge fuze tongzhi jiejian Tianjin shi daibiao de jianghua (jilugao) [Speeches of leading comrades from party centre and the Central Cultural Revolution [Group] to Tianjin representatives (transcripts)]. Tianjin, Apr. 1967.

Tianjin shi Jinnan qu difang zhi bianxiu weiyuanhui (ed) 1999. Jinnan qu zhi [Jinnan district gazetteer]. Tianjin: Tianjin shehui kexue yuan chubanshe.

Tianjin shi nongcun hezuo zhi fazhan shi bianji bangongshi (ed) 1988a. Tianjin shi nongcun hezuo zhi dashiji: 1949-1987 [Chronology of the Tianjin village cooperative system, 1949-1987]. Tianjin: Tianjin shi nongye hezuo zhi fazhan shi bianji bangongshi.

- 1988b. Tianjin shi nongcun hezuo zhi dianxing shiliao xuanbian: 1949-1987 [Selected representative historical materials on the Tianjin village cooperative system, 19491987]. Tianjin: Tianjin shi nongye hezuo zhi fazhan shi bianji bangongshi.

- 1989. Tianjin shi nongcun hezuo zhi fazhan jianshi, 1949-1987 [Concise history of the Tianjin village cooperative system, 1949-1987]. Tianjin: Tianjin shi nongye hezuo zhi fazhan shi bianji bangongshi.

Walder, A. G. 2006. 'Factional Conflict at Beijing University, 1966-1968'. China Quarterly 
188: 1023-47.

Wang Hui 2004. 'Wo suo zhidao de "Xiaozhan si qing"' [What I know about 'Xiaozhan's four cleanups']. Tianjin wenshi ziliao xuanji 102 (2): 197-218.

Wang Kangzhi jinian wenji bianjizu (ed) 2001. Wang Kangzhi jinian wenji [Collected writings commemorating Wang Kangzhi]. Tianjin: Tianjin renmin chubanshe.

Xie Yan 2004. 'Chen Boda zuo'e zai Xiaozhan' [Chen Boda commits evil in Xiaozhan]. Tianjin shi zhi 6: 15-23.

Yang, D. L. 1996. Calamity and Reform in China: State, Rural Society, and Institutional Change since the Great Leap Famine. Stanford: Stanford University Press.

Zhang Chengxian 1998. "'Wenge" chuqi de Beida gongzuo zu' [Beijing University's work team in the early stages of the Cultural Revolution]. Bai nian chao 5: 24-34.

Zhonggong Tianjin shiwei bangongting 1964a. Chen Boda tongzhi jianghua jiyao [Summary of comrade Chen Boda's remarks]. 24 Nov. 1964. Hebei Provincial Archive, 855-19-1045C.

- 1964b. Shiyi yue ershier ri wan Chen Boda tongzhi de tanhua jiyao [Summary of comrade Chen Boda's remarks on the evening of November 22] 2 Dec. 1964. Hebei Provincial Archive, 855-19-1045C.

Zhonggong Tianjin shiwei pi-Lin zhengfeng bangongshi 1974. 'Nan jiao quwei zhaokai pipan dahui henpi Lin Biao fandang jituan zhuyao chengyuan Chen Boda de fangeming zuixing' [South suburbs party committee convenes a large-scale meeting to ruthlessly criticize the counter revolutionary crimes of Chen Boda, main member of the Lin Biao anti-party clique] Pi-Lin pi-Kong jianbao, No. 67, 17 Apr. 1974.

Zhonggong zhongyang dangxiao dangshi jiaoyan er shi 1987. Zhongguo gongchandang shehuizhuyi shiqi wenxian ziliao xuanbian [Selected documentary materials from the Chinese Communist Party's socialist period]. Vol. 5. Np.

Zhongyang shouzhang jiejian Tianjin fu Jing daibiao jici tanhua huibian 1967 [Collection of central leaders' remarks on several occasions to Tianjin representatives in Beijing]. Tianjin, Oct. 1967.

\section{NOTES}

1 Chen was speaking to staff members of Red Flag and the Marxism-Leninism Research Academy who were preparing to join work teams in the four cleanups movement.

2 The full text of the directive and the accompanying report can be found in Zhonggong zhongyang dangxiao dangshi jiaoyan er shi 1987, Vol. 5: 482-518.

3 One source claims that when Mao criticized Liu Shaoqi in early January 1965, he said, 'Why did you need so many work teams? All Xiaozhan needed was one Chen Boda' (Chen Mingyang 2005). This was clearly a distortion of reality, but it reflected Mao's positive impression of Chen's handling of the four cleanups in Xiaozhan.

4 Wan Xiaotang died two and a half years later on September 19, 1966. Wan's cause of death is still in dispute: Red Guards claimed that he killed himself by overdosing on sleeping pills, while his allies said that he was in poor health and died of a heart attack. The massive crowds that attended Wan's funeral in Tianjin were criticized by central leaders as 'using the dead to oppress the living'.

5 Author interview, 3 Oct. 2005.

6 Chen Boda may have been following orders from Mao. On 15 December 1964, Mao told Liu Shaoqi that hidden land exposed during the four cleanups should not be taxed for five years. Pang and Jin 2003, Vol. 2: 1366.

7 Chen was speaking on 18 Aug. 1967, in the Great Hall of the People.

8 I thank the journal's anonymous referee for alerting me to this reference. See also Walder 2006. 